\title{
Structural analysis of mixed stands coming from natural regeneration and plantations after fire
}

\author{
Thekla Tsitsoni, Marianthi Tsakaldimi, Evagelia Simeliadou and Maria Fouska
}

\begin{abstract}
Tsitsoni, T., Tsakaldimi, M., Simeliadou, E. and Fouska, M. 2010. Structural analysis of mixed stands coming from natural regeneration and plantations after fire. - Web Ecol. 10: 32-37.
\end{abstract}

\begin{abstract}
We analyzed the structure and growth of naturally regenerated stands of Pinus brutia that mixed with planted broad-leaved and conifer species, 12 years after wildfire and examined the degree of species mix. Field data on stand structure of $P$. brutia forest were taken in spring 2009 on northern and southern aspects differing in regeneration conditions. Sixteen sample plots were selected and all individuals and their attributes measured. The results showed that in northern aspects the forest is composed of P. brutia in the over-storey and Quercus pubescens and Cupressus sempervirens in the under-storey, while in southern aspects the forest was mainly composed by P. brutia (81\%). Stem diameter distribution of $P$. brutia in both aspects followed almost a normal pattern. All P. brutia individuals were characterized by vigorous growth and good to normal stem quality. Aspect did not statistically affect structural characteristics of $P$. brutia trees and saplings. However, on the northern aspect stem diameter, height, crown length and basal area of $P$. brutia were greater than in the southern aspect. Aspect significantly affected structural characteristics of $Q$. pubescens.
\end{abstract}

T. Tsitsoni, (tsitsoni@for.auth.gr), M. Tsakaldimi, E. Simeliadou and M. Fouska, Dept of Silviculture, Faculty of Forestry and Natural Environment, PO Box 262, Aristotle Univ. of Thessaloniki, GR-54 124 Thessaloniki, Greece.

Fire is an integral part of Pinus brutia forests in Mediterranean ecosystems and post-fire regeneration has been an issue in many areas of the Mediterranean basin (Thanos et al. 1989, Thanos and Marcou 1991, Spanos 1992, Spanos et al. 2000a, 2001, Thanos and Doussi 2000, Boydak 2004, Boydak et al. 2006). Post-fire regeneration of plant communities takes place either by seeds or re-sprouting. However, under harsh regeneration conditions (e.g. steep slopes, repeated fires and erosion) other strategies such as planting or seeding of native species are often applied (Boydak et al. 2006). Planting can accelerate the rate of canopy closure especially in sites where adverse conditions prevail while enforcing ecosystem resilience (Ganatsas et al. 2004, Zagas et al. 2004). Although there are many studies on post-fire natural regeneration, only few addressed post-fire community restoration through both natural regeneration and plantings (Spanos et al. 2000b, Tsitsoni et al. 2004b, Spanos et al. 2010), and there are no studies on the structure of stands that were converted to mixed stands. Such studies are very useful in order to collect more information about regeneration of burned stands with transformation from pure monoculture Mediterranean conifer forest to mixed stands with broadleaved species, which are more stable and resilient to wild fires (Spanos et al. 2010).

Such action was attempted in Greece, in the peri-urban forest of Thessaloniki. This forest consisted of pure stands of Pinus brutia and patches of Cupressus sempervirens which came from plantations aiming at the rehabilitation of the

Accepted 10 May 2010

Copyright (C) EEF

ISSN 1399-1183 
P. brutia $\square Q$. pubescens $\square$ C. sempervirens

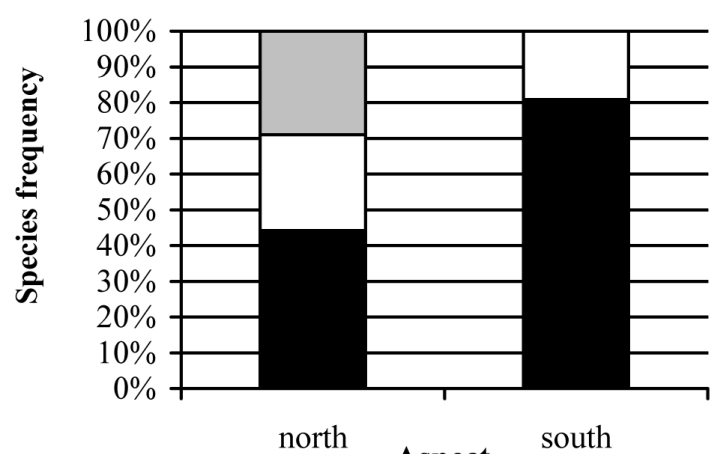

Figure 1. Species frequency in the mixed P. brutia stands on northern and southern aspects.

highly degraded ecosystem of Quercus pubescens. After the wild fire (in 1997) a large part of this pine forest was burnt, after which a large-scale plantation took place, aiming at gradual re-establishment of natural vegetation that pre-existed in the area, which belong to the 'Ostryo-Carpinion' alliance. The planted species were mainly broad-leaves of this alliance (Quercus pubescens, Celtis australis, Cercis siliquastrum, Fraxinus sp. etc.). Also, Cupressus sempervirens, which pre-existed, was planted in order to enhance the landscape value (Spanos et al. 2000b).

Thus, the objectives of this study were a) to analyze structure and growth of naturally regenerated $P$. brutia stands that mixed with planted broadleaved and conifer species in the peri-urban forest of Thessaloniki 12 years after the big wild fire, in two contrasting aspects: north vs south and b) to examine whether the conversion to a mixed forest has been fulfilled. The acquisition of knowledge on the current stand conditions will contribute to a more appropriate and complete planning of silvicultural measures for a better protection and recovery of Mediterranean type ecosystems.

\section{Material and methods}

\section{Study area}

The peri-urban forest of Thessaloniki, Greece, named Kedrinos Lofos, was selected because this forest constitutes a unique 'green belt' for a fast developing city. This forest is located in the northeastern part of the city and occupies an area of 2979 ha. The altitude of the area ranges from 50-450 m a.s.l. The climate is Mediterranean with 135 dry days on the average; the dry period lasts from the middle of May to the end of September. The mean annual precipitation is $396.7 \mathrm{~mm}$; mean annual temperature is $15.6^{\circ} \mathrm{C}$; minimum temperature of the coldest month is $6.2^{\circ} \mathrm{C}$ and maximum temperature of the warmest month is $26.0^{\circ} \mathrm{C}$, according to the data from the meteorological station of the Univ. of Thessaloniki 1981-2002. The soils of the area range from slightly acid to neutral, shallow to

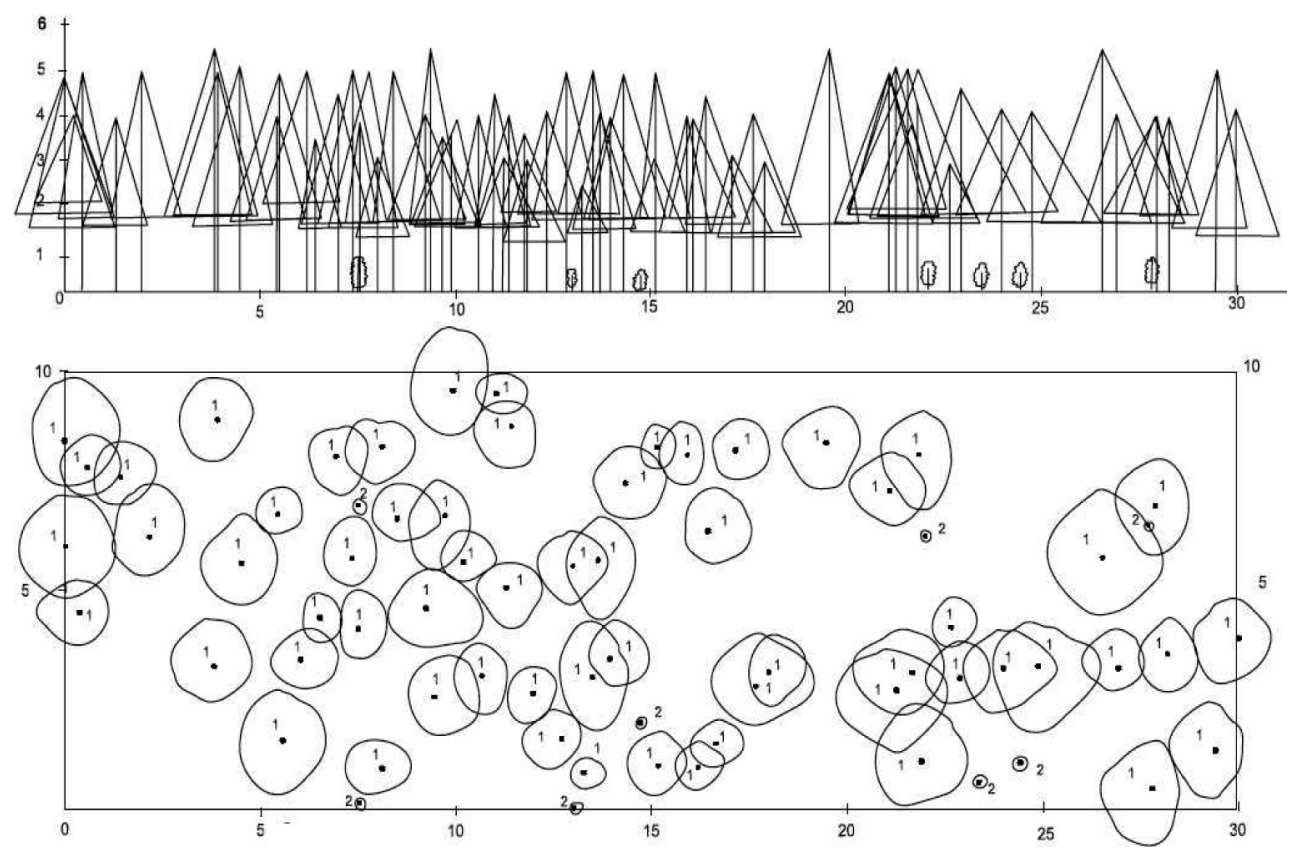

Figure 2. Representative vertical and horizontal profile of the mixed P. brutia stands on southern aspects. $1=P$. brutia, $2=Q$. pubescens. 

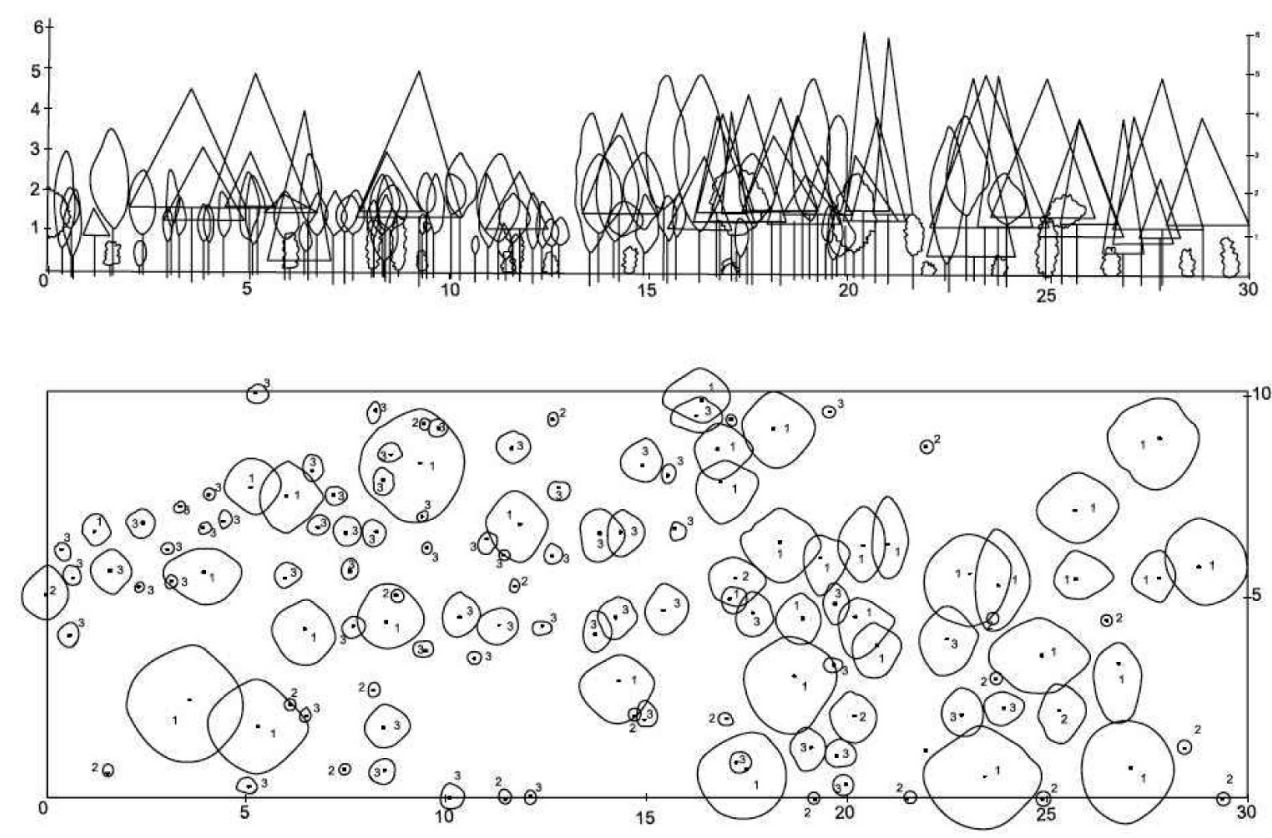

Figure 3. Representative vertical and horizontal profile of the mixed $P$. brutia stands on northern aspects. $1=P$. brutia, $2=Q$. pubescens, $3=$ C. sempervirens.

middle depth, nutrient poor and contain a high percentage of stones and pebbles. The vegetation of the area belongs to the Quercetalia pubescentis zone and especially to the 'Ostryo-Carpinion' alliance (Tsitsoni et al. 2004a). This forest was composed of reforestation, mostly of $P$. brutia age 40-50 and Cupressus sempervirens, but the big fire of July 1997 destroyed 1500 ha of it. Few months after the big fire of 1997 (Sep 97-Feb 98) eco-engineering and flood-preventing works (branch and log nettings, barriers, soil ripping) accompanied with plantings, in lines and patches of broad leaved and conifer species, in order to convert pure pine stands to mixed stands, were carried out by the Local Forest Service (Spanos et al. 2000b).

\section{Field data collection}

The field data on stand structure of $P$. brutia forest were taken in spring 2009 on northern and southern aspects where the site conditions for the regeneration are favorable and harsh, respectively. In the above areas, 16 sample plots of $300 \mathrm{~m}^{2}(10 \times 30 \mathrm{~m})$ were randomly established; eight (8)

Table 1. Structural data for naturally regenerated Pinus brutia and planted Quercus pubescens and Cupressus sempervirens individuals in the mixed stands on northern and southern aspects. Values in brackets represent SE; "significant differences $(\mathrm{p}<0.05)$ between the two aspects; D (cm): express the DBH for trees and D (at root collar) for seedlings and saplings.

\begin{tabular}{lllllllll}
\hline \multicolumn{1}{c}{ Aspect } & $\mathrm{n} \mathrm{ha} \mathrm{a}^{-1}$ & $\mathrm{D}(\mathrm{cm})$ & $\mathrm{H}(\mathrm{m})$ & $\mathrm{Cr}(\%)$ & $\mathrm{G}\left(\mathrm{cm}^{2}\right)$ & $\mathrm{L}(\mathrm{m})$ & $\mathrm{V}$ & $\mathrm{D} \mathrm{T}$ \\
\hline $\begin{array}{l}\text { Pinus brutia } \\
\quad \text { North }\end{array}$ & $1100(118)$ & $7.0(0.3)$ & $4.4(0.1)$ & $68.6(1.2)$ & $44.0(2.3)$ & $3.1(0.1)^{*}$ & $13.8(0.5)$ & $1.4(0.05)$ \\
$\quad$ South & $1617(140)$ & $6.7(0.2)$ & $4.1(0.1)$ & $67.1(0.75)$ & $38.2(1.9)$ & $2.8(0.1)^{*}$ & $14.2(0.5)$ & $1.3(0.05)$ \\
$\begin{array}{l}\text { Quercus pubescens } \\
\quad \text { North }\end{array}$ & & & & & & & & \\
$\quad$ South & $666.7(75)$ & $0.4(0.1)^{*}$ & $1.0(0.1)^{*}$ & & & $1.0(0.1)^{*}$ & & \\
$\begin{array}{l}\text { Cupressus sempervirens } \\
\quad \text { North }\end{array}$ & $383.3(42)$ & $0.3(0.1)^{*}$ & $0.7(0.1)^{*}$ & & & $0.7\left(0.1^{*}\right.$ & & \\
\hline
\end{tabular}


plots were taken per aspect. In all sample plots the silvicultural data measured or calculated in all individuals, were: the number of all individuals, the stem density $\left(\mathrm{n} \mathrm{ha}^{-1}\right)$, diameter $(\mathrm{DBH}, \mathrm{cm})$ at breast height for trees with diameter $>4 \mathrm{~cm}$, diameter $(\mathrm{D}, \mathrm{cm})$ at root collar for saplings and seedlings, basal area $\left(\mathrm{G}, \mathrm{cm}^{2}\right)$, total height $(\mathrm{H}, \mathrm{m})$, crown length $(\mathrm{L}, \mathrm{m})$, crown diameter in two directions (east-west and north-south) for the imprinting of the crown projection, and crown length \% of the tree height $(\mathrm{Cr}, \%)$. Based on these measurements, the horizontal and vertical profiles of the stands of each aspect were designed using AutoCad software. These profiles were used as a basis for the calculation of canopy cover (\%) and they reflect the real picture of the stand. Also the tree vitality $(\mathrm{V})$ and the developmental tendency (DT) were recorded according to IUFRO classification (Tsitsoni and Karagiannakidou 2000). The tree vitality $(\mathrm{V})$ is classified in three classes: grade 10 for trees of vigorous growth, grade 20 for trees of normal growth and grade 30 for trees of declining growth. The developmental tendency (DT) is classified also in three classes: grade 1 for trees with 'upward' tendency, grade 2 for trees with medium growth tendency and grade 3 for trees with descendant future growth. The stem distribution in diameter classes of $1 \mathrm{~cm}$ and in height classes of $1 \mathrm{~m}$ was carried out. Also, horizontal and vertical profiles of the stands of each aspect were made. However, only data from the tree species that contribute in a percentage above $10 \%$ are presented in this study, according to the definition of mixed stands (Dafis 1990).

Non-parametric goodness of fit test was conducted in stem distributions by using the Kolmogorov-Smirnov criterion. The relationship among the number of seedlings, diameter, and height and the other parameters on the one hand and the aspect effect on the other was tested by analysis of variance (one-way ANOVA). Data analysis was carried out using SPSS ver. 11.0 statistical program.

\section{Results and Discussion}

Twelve (12) years after the fire, the mixed stands, on northern aspects, were dominated mainly by P. brutia (42\%), Q. pubescens (27\%) and C. sempervirens (29\%). On southern aspects the mixed stands were dominated by $P$. brutia (81\%) and Q. pubescens (19\%) (Fig. 1). Participation of the other planted species was not presented because it was below $10 \%$. The mixture of the stands was per lines and patches as a result of the planting design. The canopy cover of these mixed stands was generally low; $36 \%$ on northern aspects and $44 \%$ on southern aspects, due to the higher percentage of the species $P$. brutia (see representative profiles in Fig. 2, 3). Stem density of P. brutia was higher on southern aspects (1617 individuals ha ${ }^{-1}$ ) than on northern aspects (1100 individuals ha ${ }^{-1}$ ) (Table 1). Similarly, Tsitsoni et al. (2004b) who studied the same forest 6 years after the fire, found that stem density of P. brutia on southern aspects was greater than that of northern aspects (1950 and 767 individuals $\mathrm{ha}^{-1}$, respectively). This may be explained by the greater human interventions (more plantings and soil ripping) on northern aspects, because better results were expected due to better site conditions. However, comparing our results 12 years after the fire, with those of the previous study, 6 years after the fire (Tsitsoni et al. 2004b), seems that during the last six years, stem density of $P$. brutia increased on northern aspects and decreased on southern ones (Fig. 6). Similarly, P. brutia sapling density was found by Thanos and Markou (1993), 10 years after the fire in Samos island (1500 saplings ha $\left.{ }^{-1}\right)$.

The stem density of $Q$. pubescens was greater on northern than on southern aspects (666.7 and 383.3 individuals $\mathrm{ha}^{-1}$, respectively; Table 1). This difference can be attributed either to better seedling survival on the northern aspects or to more plantings that were accomplished in these favorable site conditions.

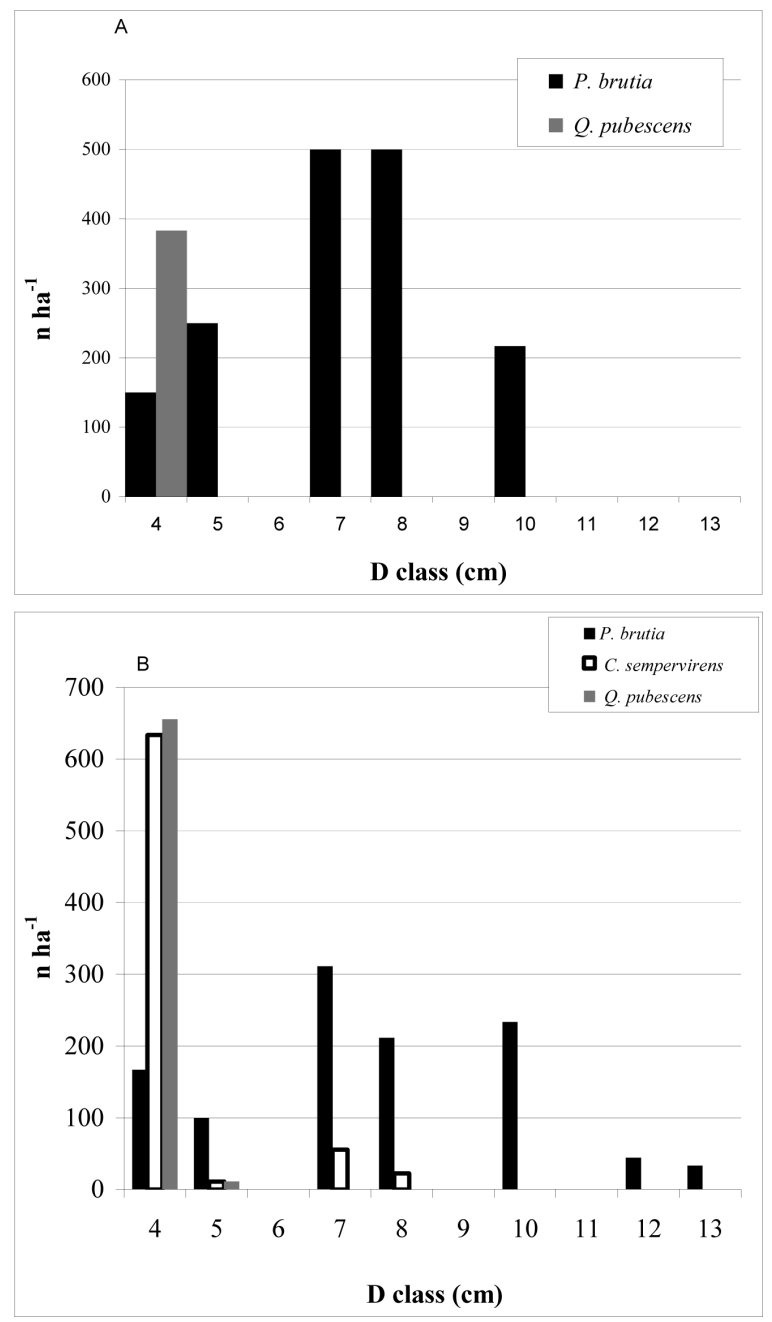

Figure 4. Distribution of diameter classes of the mixed P. brutia stands on southern (A) and northern aspects (B). 

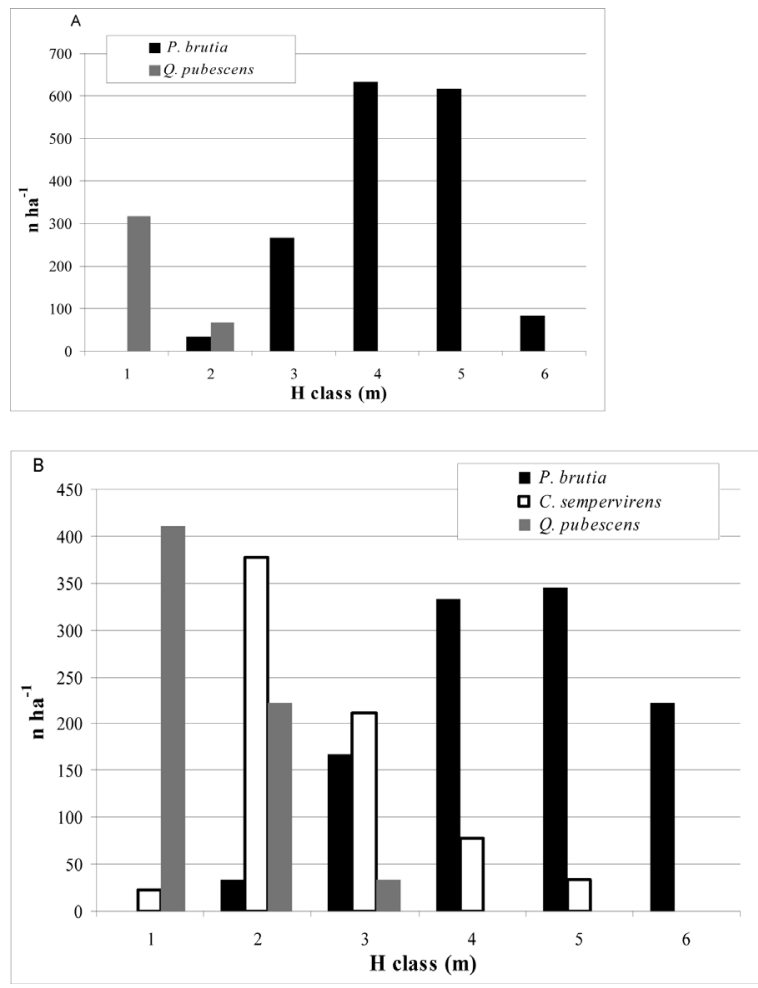

Figure 5. Distribution of height classes of the mixed $P$. brutia stands on southern (A) and northern aspects (B).

The diameter distribution of tree species can be seen in Fig. 4A and 4B. The diameter distribution of P. brutia, on both aspects, followed almost a normal pattern and varied from $4 \mathrm{~cm}$ to $13 \mathrm{~cm}$, which means that this species maintained the germination capacity of its seeds long after a fire (Dafis 1987), a fact known since ancient times as recorded by Theophrastus (Thanos et al. 1989). On northern aspects the greatest concentration of individuals appeared in the diameter class of $7 \mathrm{~cm}$. On southern aspects greatest concentrations of individuals appeared in the diameter classes $7 \mathrm{~cm}$ and $8 \mathrm{~cm}$. On northern aspects, there were individuals in the diameter class of 12 and $13 \mathrm{~cm}$, while on southern aspects the maximum observed diameter class was that of $10 \mathrm{~cm}$. This can be attributed to site conditions of northern aspects which may have favored growth (Barnes et al. 1998). However, the greatest concentration of $Q$. pubescens and C. sempervirens individuals, on both aspects, was in the diameter class of $4 \mathrm{~cm}$. This indicated that the first plantings of these species showed very low field survival, and thus, new plantings were made. The low survival may have resulted from the inappropriate method of planting or from the bad care of the seedlings (lack of watering during the first years).

The height distribution of tree species can be seen in Fig. 5A and 5B. On both aspects the mixed stands were characterized by three stories. On the northern aspects,

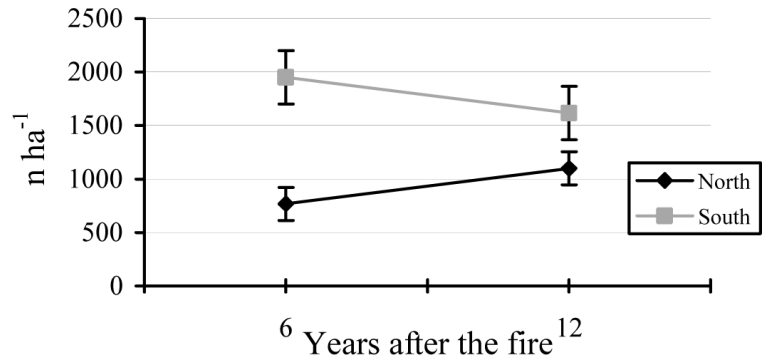

Figure 6. Stem density of $P$. brutia mixed stands on northern and southern aspects, 6 years (from Tsitsoni et al. 2004b) and 12 years after the fire.

most of the individuals of P. brutia were in the over-storey, but there were saplings also in the middle-storey. Quercetalia pubescens saplings were mainly in the under-storey, but there were also saplings in the middle-storey. Most of saplings of $C$. sempervirens were in the middle-storey, but there were some saplings also in the over-storey as well as a few in the under-storey. Similarly, on southern aspects, most of individuals of P. brutia were in the over-storey and most of the individuals of $Q$. pubescens were in the understorey. This differentiation in height distributions resulted either from the early post-fire natural regeneration of $P$. brutia or from the low survival of plantings.

The structural characteristics of tree species that dominated the mixed stands 12 years after the fire on both aspects were average to satisfactory as can be seen in Table 1 . The aspect did not significantly affect the structural characteristics of P. brutia trees and saplings with very few exceptions. However, on the northern aspects diameter (D), height $(\mathrm{H})$, crown length $(\mathrm{L})$ and basal area $(\mathrm{G})$ of P. brutia were greater than that of southern aspects (Table 1). Crown length percentage of tree height $(\mathrm{Cr} \%)$ was great enough on both aspects (approx. 70\% of the total height). This can be explained by young age of the trees and by a low canopy cover percentage. All P. brutia individuals were characterized by vigorous growth and their stem quality was good to normal. The aspect significantly affected structural characteristics of $Q$. pubescens. On northern aspects where more favorable site conditions prevailed (Barnes et al. 1998), Q. pubescens individuals had greater diameter (D), height $(\mathrm{H})$ and crown length $(\mathrm{L})$ than on southern aspects (Table 1). All C. sempervirens saplings, which dominated only on northern aspects, were characterized by vigorous growth and their stem quality was good (Table 1).

\section{Conclusions}

Based on the findings of this research on the structure of mixed stands with natural regenerated and planted species, twelve years after the fire, it seems that: 1) The aspect affected the mixture of naturally regenerated and planted species in the burned area. In northern aspects, the for- 
est was mainly composed of $P$. brutia in the over-storey, and $Q$. pubescens and C. sempervirens as a secondary stand. In southern aspects the participation percentage of the planted species was very low, while the dominant frugal species $P$. brutia reached $81 \%$. 2) The aspect did not significantly affect structural characteristics of $P$. brutia trees and saplings with very few exceptions. However, it significantly affected the structural characteristics of $Q$. pubescens, which is a more moisture demanding species than P. brutia is. 3) The canopy cover of these mixed stands was generally low due to young age of the tree stands. 4) Stem density of the naturally regenerated species $P$. brutia was lower on northern aspects than on southern aspects due to a disturbance of natural regeneration by greater human interventions. On the contrary, stem density of Q. pubescens was greater on northern than on southern aspects, as expected. 5) On both studied aspects, although many species had been planted in the study area, only very few species managed to survive and their participation percentage was below $10 \%$. The planted species that showed a better survival was $Q$. pubescens, which is in the range of its geographical distribution, and it pre-existed the pine forest (but had been displaced in the past due to intense human pressure). 6) All P. brutia and C. sempervirens individuals were characterized by vigorous growth and good to normal stem quality. 7) Finally, it can be proposed that under appropriate silvi-cultural treatments in the future, we can enhance the mixture with $Q$. pubescens and other species of the 'Ostryo-Carpinion' alliance in order to gradually re-establish the natural vegetation that pre-existed in the area, creating a more stable ecosystem, resilient to wild fires.

\section{References}

Barnes, B. V. et al. 1998. Forest ecology (4th ed.). - J. Wiley and Sons.

Boydak, M. 2004. Silvicultural characteristics and natural regeneration of Pinus brutia Ten. a review. - Plant Ecol. 171: 153-163.

Boydak, M. et al. (eds) 2006. Biology and silviculture of Turkish red pine Pinus brutia Ten. - LASER OFSET Matbaa Tesisleri San. Tic. Ltd. Sti, Ankara.

Dafis, S. 1987. Ecology of Pinus halepensis and P. brutia forests. - In: Proc. of the 1st Scientific Conf. of Hellenic Forestry Society on Pinus halepensis and Pinus brutia forests. Chalkida, 30 Sep-2 Oct 1987, Thessaloniki, pp. 17-25.
Dafis, S. 1990. Applied silviculture. - Giahoudis-Giapoulis Publications, in Greek.

Ganatsas, P. et al. 2004. Plantation contribution to restoration of degraded ecosystems in the alliance of Ostryo-Carpinion. In: Proc. of the Int. Conf. 'Protection and Restoration of the Environment VII', 28 Jun-1 Jul 2004, Myconos, Greece.

Spanos, I. 1992. Structure and regeneration of Pinus brutia in Thassos island. PhD thesis. - Dept of Forestry and Natural Environment, Aristotle Univ. of Thesssaloniki, in Greek with English summary.

Spanos, I. et al. 2000a. Post-fire, natural regeneration of Pinus brutia in Thassos Island, Greece. - Acta Oecol. 21: 13-20.

Spanos, I. et al. 2000b. Post fire establishment of plantings in the suburban forest park of Thessaloniki: first results two years after the great fire. - Dasiki Erevna 13: 11-25, in Greek with English summary.

Spanos, I. et al. 2001. Site quality effects on post-fire regeneration of Pinus brutia forest on a Greek island. - Appl. Veg. Sci. 4: 229-236.

Spanos, I. et al. 2010. Evaluation of post-fire restoration in suburban forest of Thessaloniki, northern Greece. - GNEST 2009 in press.

Thanos, C. A. et al. 1989. Early post-fire regeneration in Pinus brutia forest ecosystems of Samos Island (Greece). - Acta Oecol. 10: 79-94.

Thanos, A. C. and Marcou, S. 1991. Post-fire regeneration in Pinus brutia forest ecosystems of Samos Island (Greece): 6 years after. - Acta Oecol. 10: 633-642.

Thanos, C. A. and Marcou, S. 1993. Natural regeneration of Pinus brutia forests in Samos Island; key events during the first 10 years of the post-fire period. Int. Symp. on Pinus brutia Ten. Marmaris, Turkey, 18-23 Oct 1993. - Ministry of Forestry, pp. 176-183.

Thanos, K. and Doussi, M. 2000. Post-fire regeneration of Pinus brutia forests. - In: Ne'eman, G. and Trabaud, L. (eds), Ecology, biogeography and management of Pinus halepensis and P. brutia forest ecosystems in the Mediterranean Basin. Backhuys Publishers, pp. 291-301.

Tsitsoni, T. and Karagiannakidou, V. 2000. Site quality and stand structure in Pinus halepensis forests of north Greece. - Forestry 73: 51-64.

Tsitsoni, T. et al. 2004a. Dynamics of post-fire regeneration of Pinus brutia Ten. in an artificial forest ecosystem of northern Greece. - Plant Ecol. 171: 165-174.

Tsitsoni, T. et al. 2004b. Effect of postfire treatments on the natural regeneration of Pinus brutia in northern Greece. Proc. of 10th MEDECOS Conference 25 Apr-1 May 2004, Rhodes Greece. - Millpress.

Zagas, T. et al. 2004. Post-fire regeneration of Pinus hallepensis Mill. Stands in the Sithonia peninsula, northern Greece. Plant Ecol. 171: 91-99. 